(A. Finkbeiner Nature 477, 397-399; 2011) to report on whether it was feasible to engineer pathogens to become more lethal (for example, by making aerosolized anthrax); an unclassified summary of JASON's report says it was. In 1999, Alibek became president of a company that aimed to find antidotes to bioweapons, which got a one-year contract from DARPA. I am unsure what I am meant to make of all this.

I am sure, however, that I am intended to view as ethically dubious DARPA's decade-old launch of programmes combining artificial intelligence, autonomous robots and brain-computer interfaces. Jacobsen cites a JASON report saying that any research in this area would be subject to ethical regulation. Then, referring to work published in Nature on the capacity of the hormone oxytocin to foster trust (M. Kosfeld et al. Nature 435, 673-676; 2005), Jacobsen wonders whether soldiers might be injected with the chemical to encourage them to trust robots. And after discussing DARPA's sponsored research into limb regeneration and perhaps even human cloning, Jacobsen speculates on whether DARPA is trying to create autonomous hunter-killer robots. Such argument-by-juxtaposition is effective in fiction. In non-fiction, it is unconvincing.

Ultimately, Jacobsen's focus on DARPA's programmes sidesteps the more intractable subject of what DARPA is. She never addresses such obvious questions as how DARPA stays ahead of the next war, and whether its flexibility and responsiveness have drawbacks, for example in the ratio of risk to pay-off. Furthermore, the book promises to "shine a light on DARPA's secret history" - secret because so many of the projects are classified. Yet the text, checked against sources, shows a certain amount of creative interpretation. I know from my own reporting on JASON that Jacobsen's chapter on the electronic fence in Vietnam inspired by the group has little to do with DARPA, and that her assessment of JASON as generally central to DARPA's programmes is exaggerated.

However flawed, The Pentagon's Brain is an exciting read that asks an important question: what is the risk of allowing lethal technologies to be developed in secret? Jacobsen worries that the technology that DARPA helps to create "may itself outstrip DARPA as it is unleashed into the world". The prose might be caffeinated, but the message is serious, and has been since the first human picked up a rock and thought that it might be good for killing.

Ann Finkbeiner wrote The Jasons and is co-proprietor of a science blog, The Last Word on Nothing. e-mail:anniekf@gmail.com

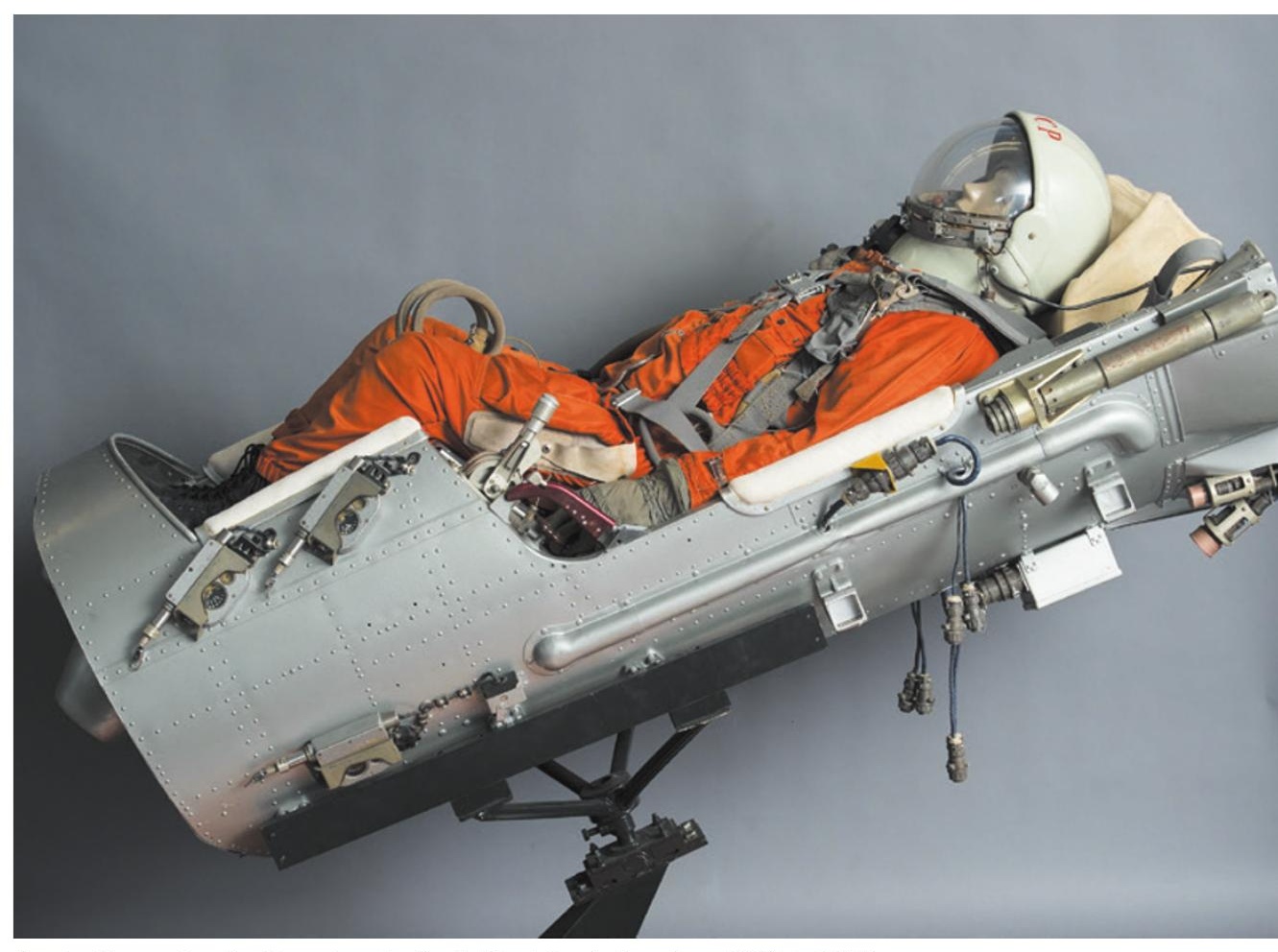

An ejection seat and suit used on the Soviet Vostok missions from 1961 to 1963.

SPACE TRAVEL

\title{
When Soviets ruled the great beyond
}

\section{Tim Radford is thrilled by an unprecedented exhibition marking the USSR's cold war feats in space.}

$\mathrm{B}$ etween the cold war years of 1957 and 1966, the Soviet Union established primacy in space. Its heady list of triumphs embraces, in the 1950s alone, the first artificial object and first animal in orbit, and the first image of the far side of the Moon. In the next decade, it grew to include the first attempt on Venus, the first man in space, the first woman in space, the first three-man mission in space, and the first spacewalk, automaton touchdown on the Moon, lunar rover (1970), and scoop of Moon rock brought back to Earth by an automaton. Reflecting the significance and extent of those triumphs, the long-awaited Cosmonauts at the Science Museum in London assembles memorabilia and engineering marvels borrowed from around a score of Russian institutes.

\section{DNATURE.COM}

For more on science in culture see:

nature.com/

booksandarts
It opens with dreams: of high orbit, free fall and exit through an airlock, sketched on paper in 1933 by schoolmaster
Cosmonauts: Birth of the Space Age Science Museum, London. Until 16 March 2016.

recumbent man-
nequin in a cradle (a "tissue equivalent phantom" flown in 1969 to absorb and measure space radiation), representing the Soviet dream of a crewed mission to Mars, and a quotation attributed to Tsiolkovsky: "Earth is the cradle of humanity, but one cannot live in a cradle forever." In between is a parade of hardware that none of us who followed the news greedily in those years had ever dreamed we might see assembled in one place, let alone in South Kensington.

The models are marvels. Here is a highly polished display model of Sputnik 1, launched in October 1957 (its chief designer, Sergei Korolev, reportedly said, "This ball will be exhibited in museums"). There are two engineering models: one of the two Lunokhod lunar rovers, the other of the once-secret lander Lunniy Korabl, designed to deliver 

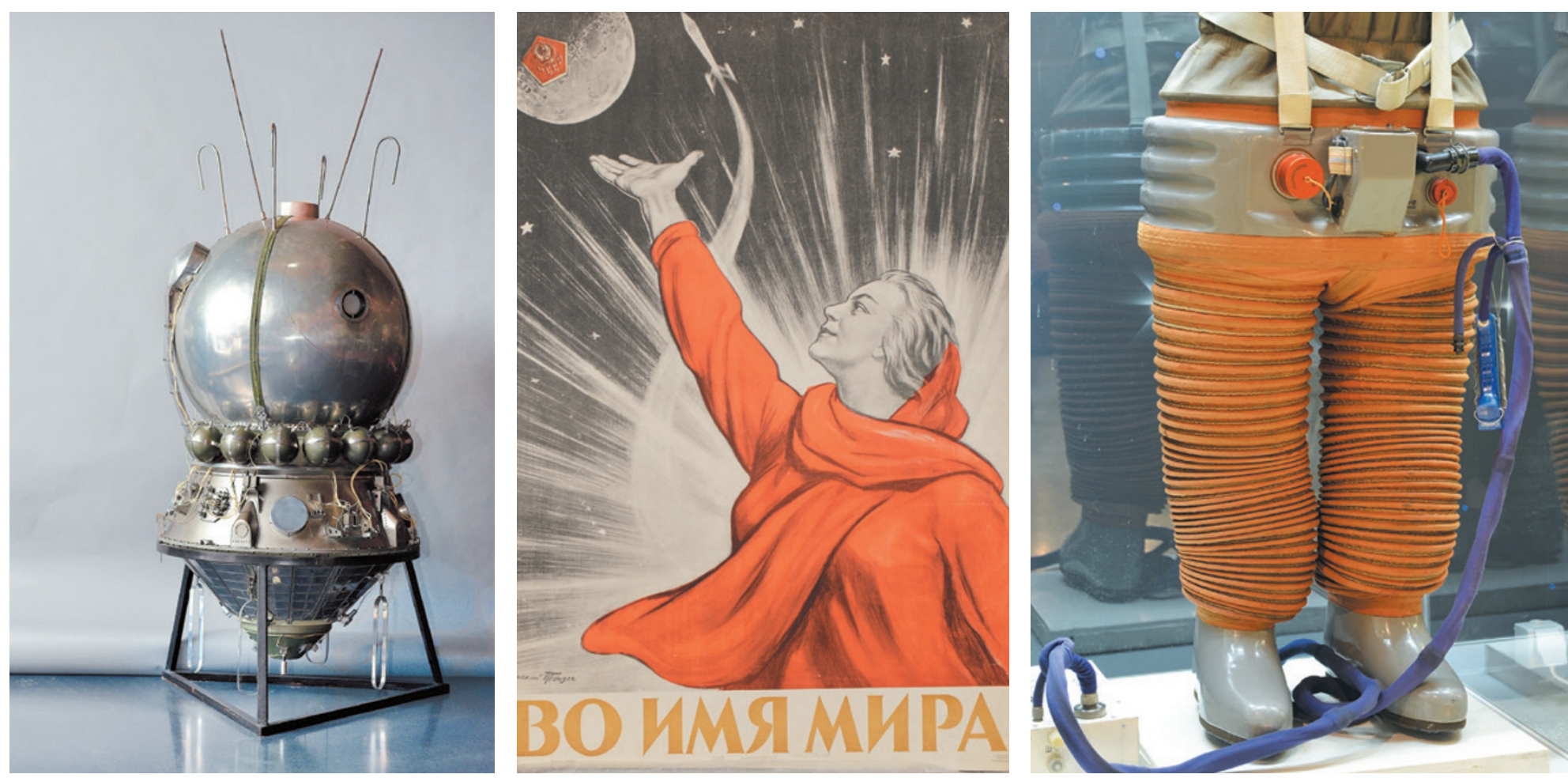

A scale model of a 1960s Vostok spacecraft; a 1959 propaganda poster, In the name of peace; and a lower-body negative pressure suit from 1971.

one cosmonaut to the lunar surface in 1969. It flew, but not to the Moon, and the rest of us knew of its existence only two decades later.

And then there are the real things. Along with the charred, three-person Voskhod 1 descent module used in 1964 is the descent module of Vostok 6. In it, cosmonaut Valentina Tereshkova orbited Earth for three days in 1963 before a return during which the heat shield was scorched by impact with Earth's atmosphere at 27,000 kilometres an hour. This is iconic stuff: the RD-108 engine that powered the space race; the complex space toilet designed to drain human waste aboard the space station Mir; the powered backpack with port and starboard lights for free flight beyond the spacecraft.

But what sets the scalp prickling are

离 the little things that tell those other $\sum$ stories implicit in this dizzying show. There is Georgy Krutikov's 1928 drawing Labour Commune, a stratospheric dream prefiguring the great adventure. And there is a little metal mug once owned by Korolev, the man most people now recognize as the driver of the space race, and thus the hero of this story.

Korolev, a Ukrainian, had been incarcerated in a prison camp in the Kolyma region of Siberia during Joseph Stalin's notorious 1930s purges. No Westerner - and few Russians - knew his name during the cold war, so closed was the Soviet world. Fresh from wartime labour detention, he arrived at the German Peenemünde base of the Nazi V-2 rocket programme to realize the dream of planetary exploration.

Sputnik 1 jolted Western complacency and helped to reignite the US space programme originally launched by the aerospace engineer and Nazi-turned-émigré Wernher von Braun. When Korolev died in 1966 during what should have been a routine operation, the new Soviet leader Leonid Brezhnev was a pallbearer. Even then, no one in the West knew of Korolev's existence.

Inevitably, the rocket engineer's genius surfaces again and again through the exhibition. There is a letter signed by Stalin authorizing the intercontinental ballistic-missile programme that made Sputnik 1 possible, and the personalized number plate YG1, used by Yuri Gagarin, the foundry worker who became a fighter pilot and, in 1961, the first man in space. There is Korolev's freehand drawing of the launch of canine cosmonauts Strelka and Belka. Alongside triumphant official Socialist realist posters there is a white lab coat daubed in red with the Russian for "Space is ours", a memento of a spontaneous 1961 celebration in Red Square. The pencils and sketch pad that Alexei Leonov took on his pioneering 1965

The space suit worn by UK cosmonaut Helen Sharman on a 1991 mission to the Mir space station. spacewalk - a near-catastrophe - are here, along with a later self-portrait of him floating at the end of a tether over the Black Sea.

The United States' role in the space race is hardly acknowledged, beyond a Time magazine cover declaring Soviet premier Nikita Khrushchev its 1957 man of the year. But the Soviet space effort seemed to lose momentum as the US Apollo programme - a story told in the Science Museum's main galleries - began in every sense to take off. Korolev's death must also have been a factor. The wonders went on, but the never-admitted race for the Moon was all but over.

This cosmic cornucopia reflects the intoxication of those first years and looks forward to the age of the space station. There is a spoon used aboard Mir by Sergei Krikalev, the man who went up as a Soviet cosmonaut and came down in 1992 as a citizen of the Russian Federation (and yes, there is a Soyuz descent module that carried a Mir crew back to Earth that year). But this unprecedented collection delivers more than a glimpse of distant exploratory technologies. It is a snapshot of Soviet history and, because the cold war warped the twentieth century, of global history, too. And where else could you see an ejector seat for a dog? The exhibits impose their own metaphors: see this show and be uplifted, transported, taken out of this world. It is the curatorial equivalent of a legal high.

Tim Radford was science editor of The Guardian in London until 2005. e-mail:radford.tim@gmail.com 